\title{
The Speech Act of Request and Refusal in English as a Foreign Language: Hotel Front Desk's Linguistic Politeness
}

\author{
Widia Yunita ${ }^{1}$ and Riki Wahyudi ${ }^{2}$ \\ Universitas STAI Hubbulwathan, Duri, Indonesia \\ riki_wahyudi@gmail.com
}

\section{ARTICLE HISTORY \\ Received : 25 August 2020 \\ Revised : 27 August 2020 \\ Accepted : 27 September 2020}

\section{KEYWORDS}

\author{
Request \\ Refusal \\ Politeness \\ Front Desk Reception \\ English in Specialised Professions
}

\begin{abstract}
The subject matter discussed in this paper is how hotel front desk receptionists handle requests and refusals in their interactions with customers when they use English as a Foreign Language (EFL). The method of this research is descriptive with a qualitative approach, examining the interactions of front desk employees who work at Hotel Surya Duri, Indonesia. The sample consists of seven people who were given a discourse completion test which questioned them on how they deal with five different scenarios of customer requests and refusals. Results showed that employees perform independent research largely on how to deal with customer requests, but overall do not adequately master how to engage with foreign customer requests and refusals in EFL. This study suggests that concerned parties may benefit training current employees in foreign language communication training.
\end{abstract}

\section{Introduction}

At this time English is the language of the phenomenon that is the time when the developed countries and developing countries use this language, in life and can't deny the state of Indonesia, has put the English language into the educational curriculum, and in addition to the language needed in work in the relationship between the State, the hospitality and tourism. Communication is the very thing in the life of one of them in the field of business like hospitality, where business which moves in the form of public service is very susceptible to interaction. As in the English language such as English, Japanese, Mandarin and German, but more focused writer in the used English language. For hospitality very satisfactory service there is a point that is very important to develop this business. And are very sure employees who work in the hospitality required to be language English as a supporting factor to increase the number of tourists or visitors who stay at hotel is business. In the hospitality front desk was very influential in improving a hotel.

Front desk as an information centre about the facilities available at the hotel facilities and as a centre for lodging transactions and use of services and handle guest complaints. The authors take the title of Investigating the production of the request and refusal by the front desk at the Hotel Surya Duri, because the front desk clerk experience problem of how to request and how to refusal devoted to foreign guests who stayed at the hotel in the form of English language which affect the hotel services.Currently, the hotel is an asset for the country in the field of tourism; English is indispensable in communicating with strangers, because the hotel is a public service. Various types of foreign nationals in stay at a hotel.
Classy where employees are able to communicate in English in accordance with the hospitality attitude. But the reality in the city of Duri some existing hotels can't be applied. Thus the researchers want to take an example of a hotel the objects at Surya Hotel.

Surya Hotel is the biggest hotel in the city-based spines 3 is located in the city 125 miles Sudirman Duri city. The hotel has been established for 14 years. In the time frame during which the hotel has been visited by many foreign guests, then the author would like to examine the form of delivery of the request and refusal of foreign guests, in terms of good communication in English. In the implementation of common miscommunication between employees and foreign guests, in the form of delivery of the request and refusal. in providing services to guests in a way of communicating, expression and responses in accordance with the standards of the hotel. Front desk was very influential in the running of such communication, any employee who works in the front desk should be prosecuted in communication good. If the front desk is not able to communicate well will get a bad impression to the guests. Front desk here valet, door men, bellboy, bell captain and receptionist, is the most important in a hotel because the front reception desk has a function serving the guest arrival and departure of individual guests, groups and guests are VIPs, gave an explanation of the hotel facilities, guest complaints handling complaints. in this case the front desk required to be able to overcome the problems to be faced, such as communication with foreign guests. how we speak, grammar hospitality to foreign guests the way we request and how we refusal.

In communication English is used in the hotel is a formal language in which the formal language is relatively 
precise used in communications and hotel services to guests. Formal language is polite language that puts the speaker, in this case the hotel guests in a respectable position it should apply to communications made to the foreign guests of the hotel employees. Polite words that were raised by a hotel employee to hotel guests, will give a positive impression to be given to employees of foreign guests, the hotel and be the first choice to stay, for local guests and foreign guests. Beebe, Takahashi, \& Uliss-Weltz (1990), "studied the refusal produced by English speakers, analyze refusal as a sequence of formulas, consisting in the case declined the invitation; expression of regret, followed by the reason, and ended up with an alternative offer".

It is expected that this study the provide a broader understanding with regard to the discourse analysis of request and refusal among employees in English to those who work are more likely to be among the speakers and foreign speakers. So that employees can develop their language better, request and refusal.

The discovery of a more general pattern of pragmatic failure as the result of a foreign language can help to find any variations and bring a positive point of view of research, particularly in the study of speech acts. In addition to the need to communicate in English in the field of hospitality needed to support the work in all matters relating to a stranger about the facilities available in the hotel. In the implementation of common miscommunication between employees and foreign guests, in the form of delivery of the request and refusal. in providing services to guests in a way of communicating, expression and responses in accordance with the standards of the hotel.

\section{Literature Review}

\subsection{Theoretical Review}

In the language of hospitality aspects of linguistic politeness, modesty and appropriateness of the English language that cannot be avoided by the hotel guests. Of course the hotel guests will not complain about the weakness of the language in communicating to their employees. But it would be appreciated if the employee to communicate with courtesy and proper (Zafrialdi, 2006, p.2).

Table 1. Theoretical Framework of the Research

\begin{tabular}{|c|c|c|}
\hline Element & Indicator & Relevant Theory \\
\hline $\begin{array}{l}\text { Speech art of } \\
\text { refusal }\end{array}$ & $\begin{array}{l}\text { The employee is } \\
\text { able to perform } \\
\text { the way refusal } \\
\text { invitation; } \\
\text { expression of } \\
\text { regret, followed } \\
\text { by the reason, } \\
\text { and ended up } \\
\text { with an } \\
\text { alternative offer. }\end{array}$ & $\begin{array}{l}\text { Beebe, Takahashi, \& Uli } \\
\text { Weltz (1990) }\end{array}$ \\
\hline
\end{tabular}

Searle \& Vandervken

$(1985: 195)$

$\begin{array}{ll}\begin{array}{l}\text { Speech art of } \\ \text { request }\end{array} & \begin{array}{l}\text { The employee is } \\ \text { able to perform } \\ \text { the way request }\end{array} \\ & \text { Taleghani-Nikazm (2006) } \\ \text { expression, } & \text { Gohl (2000) } \\ \text { "excuse," (2) the } \\ \text { request and, } \\ \text { (3) the reason } & \text { Scott (1987) } \\ & \text { Brown and Levinso (1978) }\end{array}$

\subsubsection{Speech Act}

Speech acts have been investigated and described from a variety of perspectives: Philosophical, social, linguistic and cultural. An effort has been made to identify universal norms of speech behaviour and to distinguish these from language-specific norms in order to better understand and evaluate inter language behaviour. Given a speech act such as apologizing, requesting, complimenting, or complaining, the first concern of the researcher is to arrive at the set of potentially universal realization patterns, anyone of which would be recognized as the speech act in question, when uttered in the appropriate context. We have referred to this set of strategies as the speech act set of the specific speech act (Gowasa et al., 2019).

In order to arrive at the speech act set, it is necessary to define the goals of the speech act in question and to identify performative and semantic prerequisites for the realization of these goals. As an example, consider the speech act of requesting. It was necessary to present a scale of impositives (Saragi et al., 2019), moving from the most direct to the most indirect request.

A speech act is an action performed by means of language, such as requesting something, complaining about something, or refusing something. We perform speech acts when we offer an apology, greeting, request, complaint, invitation, compliment, or refusal. Speech act theory began with the work of two philosophers, John Austin and John Searle. This concept was first introduced by Austin (1962) and later modified by his Searle (1969). According to the theory, a greeting speech acts serves as a function of communication. It allows people tosay things and do the -things they say. Speech act is the performance of actions when making a speech, usually during conversations.

\subsubsection{Request}

Brown and Levinson (1978) define 'requests' as facethreatening acts to both the requester and the recipient since it has the potential to be intrusive and demanding. A request expresses a wish for the hearer to perform some action. The speech act of requesting generally has three levels depending on the degree of directness. First, the most direct and explicit level (e.g. performatives and hedged 
performatives). Second, the conventionally indirect level (e.g. requests that realize the act by referring to contextual preconditions necessary for its performance, as conventionalized in a given language). Third, the nonconventional indirect level (e.g. the open-ended group of indirect strategies that realize the act by either partial reference to an object or element needed for the implementation of the act).

A request is to ask someone to do/not do something or to express the need or desire for something. The speech act of a request has been considered a noteworthy subject for the research of speech acts because requests are 'FaceThreatening Acts (Yong-Ju Rue, 2008:1).

The purpose of a request is to get the addressee to do something (Level 1989: 60). In most cases, the intent of a speaker making a request is to require the addressee to perform some kind of action which is of benefit to the speaker at the cost of the addressee .To achieve this, the speaker needs to employ strategies and modifications that will minimize the potential imposition of the illocutionary act of a request that threatens the addressee's face and may give the addressee burden, to some extent. For this reason, the speaker should attempt to achieve an effective outcome of the intended request from the addressee by utilizing less impositive request strategies.

A speech act of requests is a prominent event in daily interactions, one in which the speaker usually manipulates appropriate linguistic forms to make requests according to certain situations. For example, under the influence of the growing promotion of business and trade affairs between China and Korea, the tactics of interpersonal communication, particularly making appropriate requests, have become of considerable interest because of their function in maintaining or developing discussion and leading to successful cooperation. In order for Chinese and Korean companies to negotiate successfully for the sake of their trade and business goals, they need to develop communicative competence by examining cross-linguistic differences and appropriate language use in cross-cultural communication

Speech act of request in these studies is that it's modes of performance carry heavy social implications and seems to be ruled by universal principles of cooperation and politeness (Sapitri et al., 2020). Thus, in a requisite situation, researchers might find more politeness in the interactants' language (Taleghani-Nikazm , 2006: 2).

Of the above theory to generate speech acts in the delivery request in politeness in requisite situation. Language is a universal communication tool; in this case the researchers took the title of investigating the production of the request and refusal by the front desk at the Surya Hotel Duri which focuses on how to follow speech requests and hostage in order refusal by the states speech act is an act which is done by means of language, such as asking for something, complain about something, or reject something, offering an apology, greeting, requests, complaints, invitations, compliments, or refusal.

Where is the speaker of the theory must establish cooperation, courtesy and know the situation request that you want to convey speech and action in the request in performing the request of the speaker should be clear what who wants to be asked to stay away from the problem of communication between the speaker in the delivery of speech acts request.

Request in everyday conversation refers here to the type of social action in which interactional goal of the first speaker is to get his co-participants to the performance measures (i.e., transfer something of value, such as an object, service or information) is for the benefit of the first speaker or a third party. The requested action can be performed at the time of speaking or at some later point (Taleghani-Nikazm, 2006: 1). The speech act must be preceded by a good conversation in view the circumstances and towards what you want to be asked. To avoid communication problems in speech act must take the discourse request speaker said this component are: (1) the expression, e.g., "excuse," (2) request, e.g., "please deposit the room" and, (3) the reason, e.g., "because the room bill already over limit of provisions which specify."

Relatively precise language used communications and hotel services to guests is a formal language, formal language is a language polite and put the other person, in this case a hotel guest, in a respectable position. spoken word, especially the front desk will give a positive value for hotel guests.

There are a number of keyword if the words are inserted in the sentence to replace the words would change the sentence into a sentence or polite or formal language sure, certainly, fine, of course, all right, please, would, could, should, have, may, afraid, apologize.

\subsubsection{Refusal}

A refusal is to respond negatively to an offer, request, invitation, etc. Searle and Vandervken (1985:195) define the speech act of refusal as follows: "the negative counterparts to acceptances and consenting are rejections and refusals. Just as one can accept offers, applications, and invitations, so each of these can be refused or rejected". It is so difficult for some non-native speakers to say "no". In many cultures, how one says "no" is probably more important than the answer itself. Therefore, sending and receiving a message of "no" is a task that needs special skill. The interlocutor must know when to use the appropriate form and its function depending on each group and their cultural-linguistic values. The skills of refusing others' offers, requests, or invitations without hurting their feelings are very important to have since the "inability to say 'no' clearly has led many non-native speakers to offend their interlocutors". 
Refusal is considered a face-threatening act among the speech acts for it threatens the face wants of the speaker and the hearer by running contrary to their face wants. The face of the speaker or listener is risked when a refusal is called for or carried out. Consequently, refusals, as sensitive and high-risk, can provide much insight into speaker's pragmatics. To perform refusals is highly indicative of one's non-native pragmatic competence (AlKahtani, 2005:2).

Rejection is a very complex speech acts, especially since they may involve lengthy negotiations and facesaving manoeuver. Because rejection usually serves as part of both spouses, they preclude extensive planning on the part of the person who refuses. A rejection is done with the involvement of negotiations in which the negotiations are lists of planning done by some people who do not have the same mission. Beebe, Takahashi, \& Uliss-Weltz (1990) studied the refusals produced by English speakers, and their analysis found that rejection is a sequence of formulas, consisting of invitation declination or expression of regret, followed by the reason, and ended up with an alternative offer.

English is a communication tool for employees who work in the hospitality, the hotel is a business that is engaged in services, especially for domestic tourists and international tourists and is the largest producer of the State deficit. Hearing the words, for sure we will think about the tourists, indirectly we will think about the English language. English is the international language. And some of hospitality requires employees are able to speak English, which would refer to the hotel itself in increasing the income, the more guests staying in the eyes of the better guest service. And in fact seen the hotel employees are often constrained in English in conversation with foreign guests in the delivery form and manner requested refuse in service and make foreign guests feel uncomfortable. According to of the opinion concluded by rejecting expression can be formulated with regret, in the follow reason and ended up with an offer that alternative resulting in a relevant conversation, and reduce problems in dealing of talks.

Speech act of refusal occurs when the speaker directly or indirectly, to say no to a request or invitation. Rejection is a face-threatening act for the listener/applicant/inviter, because contrary to his expectations, and often manifested through an indirect strategy. As such, it requires a high level of pragmatic competence (Chen, 1996: 2).

Chen (1996: 2) used a formula to analyze the semantics of speech acts set refusal (rejected requests, invitations, offers and suggestions) that is produced by American and English speakers. He found that the direct refusal (i.e., "No") is not a common strategy for each subject, regardless of their language background the word "NO" is a direct denial and refusal indirectly is a face-threatening act for the listener/applicant/inviter, because contrary to his expectations, and often manifested through an indirect strategy. As such, it requires a high level of competence pragmatic. So that refusal can be done either in accordance with the circumstances in the expected.

Beebe, Takahashi, \& Uliss-Weltz '(1990) study of refusal. The responses of native English speakers were reviewed for evidence of the general components of speech acts set to build a basic response set. Of theories and concepts can be done over the rejection generated by English speakers, analyze rejection as a sequence of formulas, consists in the case declined the invitation; expression of regret, followed It reason, and ending with an offer alternative. And there is a concept in which the concept of how to perform denial.

Refusal is a face-threatening act for the listener/applicant/inviter, because contrary to his expectations, and often manifested through an indirect strategy. As such, it requires a high level of competence pragmatic and direct refusal semantic formulas used to analyze the speech act set rejection (rejected requests, invitations, offers and suggestions) that is produced by American and English speakers. He found that the direct rejection (i.e., "No") concept of denial of a foreign guest rooms requested exchange cause want a new atmosphere while rooms are available is no longer so as where by refusing refusal.

First a quick refusal required demand speaker exchange the same room but the room was not there anymore. These components are: (1) the expression of regret, "Sorry," (2) reasons, "because there are no rooms available," and, (3) offer an alternative, "tomorrow will move with the same type of room?" The sentence example may be, "I'm sorry sir, I'm afraid there's no vacant room for today. Would you want me to order it to another hotel?"

The word "sorry" expresses a concern or a very good speech in the refusal in a condition, and reasons for refusal to declare a state under these conditions and offer an alternative. The refusal of the concept of the above certainly understands and appreciates the hotel guests of the language to communicate to their employees. And feel appreciated if employees communicate with courtesy and proper to foreign guests.

Social action requested has received much attention in the field of linguistics and applied linguistics. The majority of studies in this field have investigated the activity of asking for the purpose of exploring and contrasting strategies of politeness in different cultures. speech act requests in this study is that the mode of performance carries heavy social implications and it seems to be governed by universal principles of cooperation and courtesy; thus, in a situation requisite, researchers may find more politeness in language many related research explores how the speakers showing through the sequence of their 
utterances, their organizational orientation preferences request.

Specifically, this study examines the ways in which the speaker design turn while engaged in activities dispreferred to request. In particular, this analysis focuses on ways to manage the speakers move afflictive conversation when request. This is achieved by a detailed analysis of the composition of grammatical utterances speaker in a sequential and contextual environment making the request, and the type of social.

This study builds upon the body of work, and expand the discussion of grammar and interaction by focusing on one particular social action, namely that the demand in everyday conversation. As mentioned in the previous section, social action request has been described by analysts' conversation as "disprefered" practice compared to bidding. Thus, the speakers utilize interactional device for projecting the possibility of demand and therefore to prevent the occurrence of such disprefered action. In addition, when produced, the first part of the request may indicate the format disprefered action. Social action request chosen for this study because it provides a useful site to explore ways of grammar closely intertwined with interactional activities in which people engage.

\subsubsection{Front Desk}

Front desk is part of the registration of all guests who come to stay at the hotel and also explained about the facilities and is a centre of the hotel, and is the place where the activities of the hotel gives guests a first impression, also the last impression of the hotel overall (Sulastiyono,1992, p.65). Front desk has a role and function of selling within the meaning of renting out rooms to guests to assist the implementation of the function of the front desk, the front desk is divided into sections that each section has a different service functions. As for the parts that are on the front desk, reservation service, bellboy, desk service, information service.

\subsection{Relevant Research}

The research was relevant with Budi Indra Syahdewa research, university Pendidikan indonesia,2014. The research entitled is "Model Training English For Specific Purposes For The Improvement Of Communication Skills Front Office Clerk At The Hotel Aston Network." the writer uses descriptive research which analyze the data by quantitative research and in support of qualitative data in accordance with the results of the test communication skills and interview.

This study has formulated on how is the model training English for specific purposes for the improvement of communication skills front office clerk at the hotel aston network. Based on the research, it can be summarize English for specific training model for improvement of communication skills purposes front office clerk at the hotel aston network, have the result $26 \%$ or $27 \%$ the foreign guests who want to stay to experience the process easy, from 10 front office clerk things that need to be improved, especially in English for specific purposes grammatical and vocabulary development in front office clerk, proficiency is not only able to understand the message and as well as the delivery of messages.

Communication skills is on the understanding of communication as a means of communication with the guests of different cultures within the framework of the friendly service, the officers understand the language used group of foreign guests.

The research was relevant with Sharyl Tanck research, The paper received an AU TESOL Academic Excellence Award for 2002-2003." Speech Act Sets of Refusal and Complaint a Comparison of Native and Non-Native English Speakers' Production" the writer uses descriptive research which qualitative with the test Discourse Completion Tests, where in they were asked to write their responses. to six prompts, representing the two speech acts and two distractors, within familiar equal and superior-inferior relationships.

This paper investigates the differences between native and non-native English speakers' production of refusals and complaints. It is hoped that this study, with subjects who represent a wide range of first languages, will provide a more broad understanding of the discrepancies that can exist between native and non-native complaints and refusals.

This study has formulated on how is the speech act sets of refusal and complaint a comparison of native and nonnative English speakers production Based on the research $60 \%$ of the non-native speakers reported using English "often," "everyday," or "all the time," while 40\% reported using English "not often," or only at school or work for 25 person.

\section{Method}

This research is designed as a descriptive research with qualitative approaches, using training process to reveal how Hotel Surya Duri employees deal with foreign guests' requests and refusals. Surya Hotel is a hotel located in the city of Duri, Riau province, Indonesia. Located in the Sudirman Km 125 Duri built in 2000 and is the largest hotel in the city of Duri which has a total staff of about 85 people and is made up of 8 departments, and from several departments such as front office, housekeeping, kitchen, accounting, stores, security, engineering and food and beverage. And from several departments such as front office, housekeeping and food and beverage must master the English language in communications to customers, especially foreigners.

The study targeted the employees of departments devoted to the front office, finding seven office employees who have different accents, attitudes and speech styles when they speak English. Their specific occupations are listed in Table 1. 
Table 2. Distribution of Population and Sample of the Research

\begin{tabular}{lccc}
\hline \multirow{2}{*}{ Front desk } & \multicolumn{2}{c}{ Gender } & \multirow{2}{*}{ Total } \\
\cline { 2 - 3 } & Male & Female & \\
\hline Bellboy & 2 & - & 2 \\
Reservation & 1 & 1 & 2 \\
Information & 1 & 1 & 2 \\
Service & & & \\
Desk Service & - & 1 & 1 \\
\hline & 4 & 3 & 7 \\
\hline
\end{tabular}

To obtain the employee's ability to perform speech acts, requests and refused, researchers give a written test to measure the ability of the employee, such as hotel employees have been given training and good communication standards in communication according to standard hotels, and be a positive point for measuring the extent to which employees the master and the communication of understanding expected by management.

Researchers took the time to research on investigating the production of request and refusal by the front desk at the hotel surya. For 3 month from the date of 1 April 2015 to 30 June 2015 in conducting action research request and refusal speech so that within a month the researchers get results from the ability of the hotel staff, in their communication in speech act of request and refusal to foreign guests.

To obtain the data needed for this research, the study used a Discourse Completion Test (DCT) which consists of two types of instructions meant to obtain specific speech acts, in this case designated as responses to foreign customer requests and refusals in simulated hotel scenarios. The study made the situation in performing the way the request and refusal. Test consists of 5 items situation by allocating 30 minutes for all tests. The employees answer in the answer paper has been prepared.

This research is based on measuring the understanding and ability of hotel employees, to determine the extent of the ability of employees serve foreign guests in ease of communication in making a request and refusal to foreign guests. The majority of the employees of the said act is often a problem of communication, in the form of delivery is not good, and the resulting foreign guests to be uncomfortable. So researchers are looking for solutions that are good communication to the foreign guests were good.

It is expected that this study will provide a broader understanding with regard to the discourse analysis of request and refusal among employees in English to those who work are more likely to be among the speakers and foreign speakers. So that employees can develop their language better, request and refusal the discovery of a more general pattern of pragmatic failure as the result of a foreign language can help to find any variations and bring a positive point of view of research, particularly in the study of speech acts. In addition to the need to communicate in English in the field of hospitality needed to support the work in all matters relating to a stranger about the facilities available in the hotel so as to increase the quality of the hotel, and the quality of the hotel employees. In doing good, so communication creation of a comfort felt by the foreign guests, and make the hotel into the best choice in lodging.

In standard value will be focus with component for Refusal These components are The expression of regret, "Sorry," The reasons, An offer of alternative and Request These components are The expression, "Excuse," Request The reason.

\section{Results}

The data were obtained from the result of data collecting. That was employed frequency on the discourses completion test of production request and refusal by front desk at Hotel Surya Duri. The test consists of 5 items and total assessment of how many answers were taken from the three components that meet the written request and the refusal and good score of the test be showed in component about refusal The expression of regret, "Sorry," The reasons, An offer of alternative. And good score look in request components are: The expression, "Excuse," Request, The reason. the percentage taken out of every situation that is attached authors in test request and refusal.

Table 3. Employees' Production of Requests and Refusals

\begin{tabular}{ccccc}
\hline Situation & \multicolumn{2}{c}{ Requests } & \multicolumn{2}{c}{ Refusals } \\
\cline { 2 - 5 } & Good & $\begin{array}{c}\text { Not } \\
\text { good }\end{array}$ & Good & Not good \\
\hline 1 & 3 & 4 & 3 & 4 \\
2 & 3 & 4 & 6 & 1 \\
3 & 3 & 4 & 7 & 0 \\
4 & 3 & 4 & 3 & 4 \\
5 & 5 & 2 & 5 & 2 \\
\hline
\end{tabular}

In collecting the data, the writer give the test discourses completion test speech act: investigation the production of request and refusal by front desk at surya hotel duri. test score of the test be showed in component about refusal The expression of regret, "Sorry," The reasons, An offer of alternative and Request, These components are: The expression, "Excuse," Request ,The reason. and can be seen from the data below production request and the refusal of the test is given in the form of discourses completion test in accordance with the component.

Table 3 shows that in the situation in the first three employees make requests either did not request and either do demand there are four employees who are not good. And in the second situation, three of the employees make requests well and while four of them did not ask to no good. 
And the situation of their third and fourth situations, the employee who is able to ask well just three employees and four of them are not good. And the situation fifth, five employees asked nicely while the two are not good.. From the above data, that means asking good component refers to the request. The expression, "Excuse," Request, the reason.

Meanwhile, in the situation refusal in the first three good and four not good and from situation two in production refusal, for six employee good and one not good, and situation three in production refusal, for seven employee good and not good nothing. And situation four in production refusal for three employee good and four employee not good and situation in production refusal for five employee good and two employee not good. In data focus to the component refusal component about refusal the expression of regret, "Sorry," The reasons, an offer of alternative.

From the Table 3, this study can assess how to shape how to request and how to refuse in accordance with the existing standard component in the indicator of request and refusal invitation by assessing how many people do I request and refused to refer to the component .where we take 5 different situations that refers to how we asked and refused to foreign guests.

To know the percentage of speech act: investigating the production of request and refusal by front desk at Surya Hotel Duri, in the test, the writer using formula:

$$
P=\frac{F}{N} \times 100 \%
$$

Where:

$$
\mathrm{P}=\text { Percentage }
$$$$
\mathrm{F}=\text { Frequency }
$$

$\mathrm{N}$ = Total number of employed' (Sudjana, 1989: 50)

Table 4. The Results of the Employees Request Speech Act Performance

\begin{tabular}{ccc}
\hline Situations & Description & Employee \\
\hline 1 & Good & $42.8 \%$ \\
& Not good & $57.2 \%$ \\
2 & Good & $42.8 \%$ \\
& Not good & $57.2 \%$ \\
3 & Good & $42.8 \%$ \\
& Not good & $57.2 \%$ \\
4 & Good & $42.8 \%$ \\
& Not good & $57.2 \%$ \\
5 & Good & $71.4 \%$ \\
& Not good & $28.6 \%$ \\
\hline
\end{tabular}

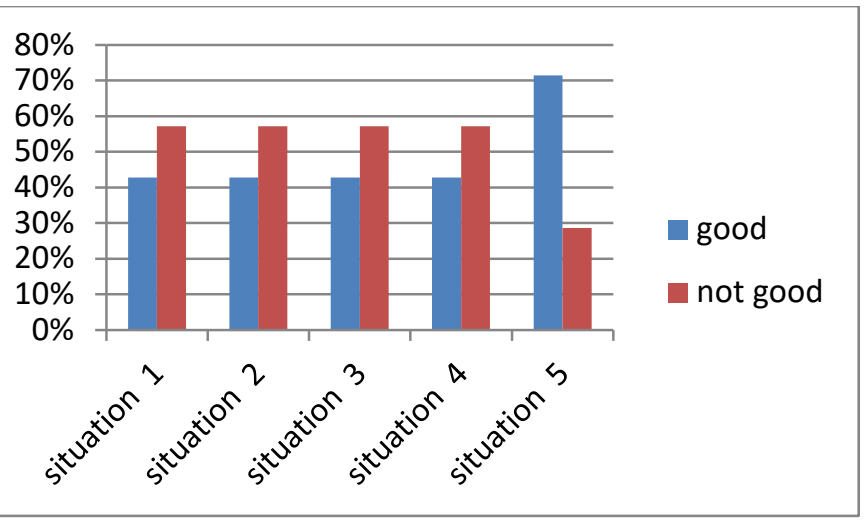

Figure 1. Frequency of Request Speech Production

From the table above we can see what percentage of employees who did request that refers to the visible indicator of the situation that is given to perform the way the request, resulting from the situation 1 in process check in employed ask for a passport as one of the procedures in registration. in the result of $42.8 \%$ perform well request and $57.2 \%$ did not perform well. And in the second situation in process transaction room employed ask payment additional deposit and result $42.8 \%$ perform well request and $57.2 \%$ did not perform well. And situation three about in process check out and all cost accommodation will charge to company and employed ask all the bill in sign of customer. And result $42.8 \%$ perform well request and $57.2 \%$ did not perform and situation to four about process reservation by phone, employed ask for the identity and arrival time are going to write the data reservation and result $42.8 \%$ perform well request and $57.2 \%$ did not perform well and the fifth situation about process check in employed ask guaranteed latter for guest staying long stay in result $71.4 \%$ perform well request and $28.6 \%$ did not perform well.

Table 5. The Results of the Employees Refusal Speech Act Performance

\begin{tabular}{ccc}
\hline Situations & Description & Percentage \\
\hline 1 & Good & $42.8 \%$ \\
& Not good & $57.2 \%$ \\
2 & Good & $85 \%$ \\
& Not good & $15 \%$ \\
3 & Good & $100 \%$ \\
& Not good & $0 \%$ \\
4 & Good & $42.8 \%$ \\
& Not good & $57.2 \%$ \\
5 & Good & $71.4 \%$ \\
& Not good & $28.6 \%$ \\
\hline
\end{tabular}




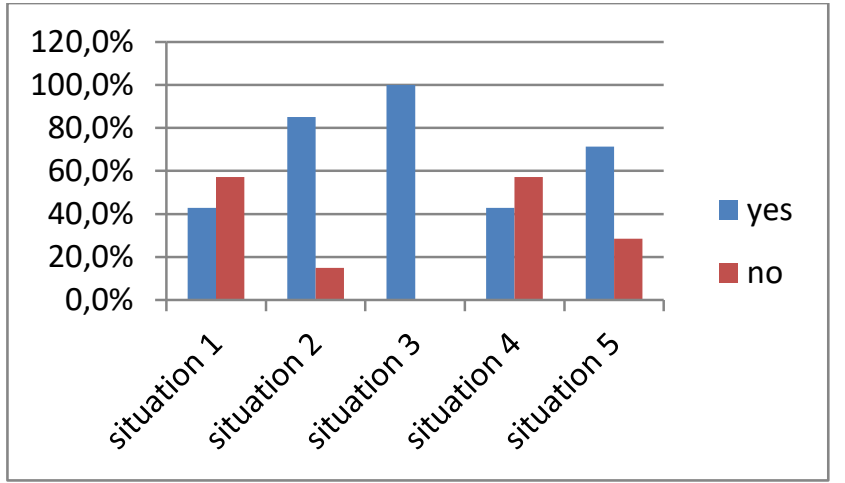

Figure 2. Frequency of Refusal Speech Production

From the table above can be seen in the denial of the percentage of foreign guests, from 5 situation is viewed, obtained varying results, which at first situation produced denial employees in accordance with the existing components with utter expressions of regret, "sorry", the reason, an offer of alternative. from the situation 1 about process check in and while the room are in a state of full, in the result of $42.8 \%$ perform well refusal and $57.2 \%$ did not perform well. And in the second situation about the process cancel check in while all transaction have been carried out. And customer asked for his money back and result $85 \%$ doing well refusal and $15 \%$ did not perform well and the third situation about the guest want the change room but in condition room full today. how do you do a refusal and result $100 \%$ doing well and the situation to four about process check out and all accommodation cost are charge to the guest but guest ask the payment charge to company, how the refusal to guest and presentation $42.8 \%$ doing well and $57.8 \%$ did not perform well the fifth situation about no smoking area. so in employed refusal no smoking area in lobby and result $71.4 \%$ perform well request and $28.6 \%$ did not perform well.

Based on the data analysis, the result of the test about how the front desk to request foreign guests, where a request has to perform some component of the component in which researchers could assess how the front desk did request in accordance with such component. The expression, "Excuse," do "Request" and "The reason" so that researchers result of the test that is given to the front desk employed.

Resulting from the situation 1 in process check in employed ask for a passport as one of the procedures in registration. in the result of $42.8 \%$ perform well request and $57.2 \%$ did not perform well. And in the second situation in process transaction room employed ask payment additional deposit and result $42.8 \%$ perform well request and $57.2 \%$ did not perform well. And situation three about in process check out and all cost accommodation will charge to company and employed ask all the bill in sign of customer. And result $42.8 \%$ perform well request and $57.2 \%$ did not perform and situation to four about process reservation by phone, employed ask for the identity and arrival time are going to write the data reservation and result $42.8 \%$ perform well request and $57.2 \%$ did not perform well and the fifth situation about process check in employed ask guaranteed latter for guest staying long stay in result $71.4 \%$ perform well request and $28.6 \%$ did not perform well.

The result of the test of how the front desk to the rejection to the foreign guests. where to perform a denial has some component of the component in which researchers can assess how the front desk to the rejection in accordance with such component. The expression of regret, "Sorry," do "the reason" and "an offer of alternative" so that researchers gain the results of a test that is given to the front desk employee. And resulting from the situation 1 about process check in and while the room are in a state of full, in the result of $42.8 \%$ perform well refusal and $57.2 \%$ did not perform well. And in the second situation about the process cancel check in while all transaction have been carried out. And customer asked for his money back and result $85 \%$ doing well refusal and $15 \%$ did not perform well and the third situation about the guest want the change room but in condition room full today. how do you do a refusal and result $100 \%$ doing well and the situation to four about process check out and all accommodation cost are charge to the guest but guest ask the payment charge to company, how the refusal to guest and presentation $42.8 \%$ doing well and $57.8 \%$ did not perform well the fifth situation about no smoking area. so in employed refusal no smoking area in lobby and result $71.4 \%$ perform well request and $28.6 \%$ did not perform well. Percentage of results obtained from the data. result from the five situation given on how to carry out the request and refusal which refers to an indicator component contained in the produced results that vary from the request and refusal.

\section{Conclusion}

Hotel employee service is not absolute or identical because how they deal with requests and refusals are not the same. $42.8 \%$ were found to be 'good' at dealing with requests, but $57.2 \%$ were not good, and these numbers are roughly reflected from the first to the fourth situations. It is only in the fifth situation that $71.4 \%$ showed a 'good' performance. Meanwhile, the simulations of refusal situations showed that $42.8 \%$ were 'good', while the results on the way that does not reject either reached $75.2 \%$, the two-way situation to a good refusal reached $85 \%$, the well not reach $15 \%$. In the third situation in particular, all participants $(100 \%)$ performed 'good' refusals without any errors. In the fourth situation up to $42.8 \%$ did 'good' refusals, but this number increased to $71.4 \%$ in the fifth situation. Overall, the data mainly captured typical expressions used in the speech act of requests and refusals, so the front desk service in hotel Surya Duri, at least in the parameters of this study, is considered 'average'.

Based on the results of this study, future studies could look into the management of front desk service's communication with foreigners. Typical management is motivating employees and giving them awards which reflec their service quality, but other routes that would improve 
the technicalities of the service should be explored. Moreover, this study is limited to the speech acts used by the employees, so future studies could tackle the nonspeech aspects, such as body language and attitude.

\section{References}

Beebe, L. M., Takahashi, T., \& Uliss-Weltz, R. (1990). Pragmatic transfer in ESL refusals. Developing communicative competence in a second language, 5573.

Searle, J. R. (1969). Speech acts: An essay in the philosophy of language (Vol. 626). Cambridge university press.

Searle, J. R., \& Vanderveken, D. (1985). Speech acts and illocutionary logic. In Logic, thought and action (pp. 109-132). Springer, Dordrecht.

Taleghani-Nikazm, C. (2006). Request sequences: The intersection of grammar, interaction and social context (Vol. 19). John Benjamins Publishing.

Al-Kahtani, S. A. W. (2005). Refusals realizations in three different cultures: A speech act theoretically-based cross-cultural study. Journal of King Saud University, 18(1), 35-37. Sudjana. (1989). Metoda Statistika. Tarsito. Bandung

Sapitri, P. A., Chasanah, A., Putri, A. A., \& Paulima, J. (2020). Exploring Brown and Levinson's Politeness Strategies: An Explanation on the Nature of the Politeness Phenomenon. REiLA : Journal of Research and Innovation in Language, 1(3), 111117. https://doi.org/10.31849/reila.v1i3.3801

Sulastiyono, A. (1999). Manajemen Penyelengara Hotel. Alfabeta.

Zafrialdi, M. (2008). English for Hotel Services. Kawan Pustaka. Jakarta

Gowasa, N. S., Radiana, S. P., \& Afifah, N. (2019). A Study on the Use of Speech Acts: A Review of Selected Paper. ELSYA: Journal of English Language Studies, 1(2). https://doi.org/10.31849/elsya.v1i2.3528

Saragi, V., Nuratika, S., Fransiska, F., Yolanda, M., \& Ardiyanti, N. (2019). A Review of Some Speech Act Theories Focusing on Speech Acts by Searle (1969). ELSYA: Journal of English Language Studies, 1(2), 60-68. https://doi.org/10.31849/elsya.v1i2.3529

Syahdewa, B. I. (2014). Model Pelatihan English For Specific Purposes Bagi Peningkatan Kecakapan Berkomunikasi Petugas Front Office Pada Jaringan Hotel Aston: Studi di Hotel Grand Aston Medan (Doctoral dissertation, Universitas Pendidikan Indonesia).
Tanck, S. (2002). Speech act sets of refusal and complaint: A comparison of native and non-native English speakers' production. Studies in Second Language Acquisition, 13(1), 65-81. 